\title{
PENGAWASAN ANGGARAN DITINJAU DARI BUDAYA LOKAL MAKASSAR DALAM KONSEP GOOD GOVERNANCE
}

\author{
Muh. Nur Sucipto Rahman \\ Universitas Muslim Indonesia Makassar \\ Email: Muhammadsucipto21@gmail.com \\ Fadliah Nassaruddin \\ Universitas Muslim Indonesia Makassar \\ Email: fadliahnassaruddin@umi.ac.id \\ Darwis Lannai \\ Universitas Muslim Indonesia Makassar \\ Email: darwislannai@umi.ac.id
}

\begin{abstract}
The purpose of this study is to determine the correlation between good governance and siri 'napacce in guarding the realization of village funds and to know the application of culture and local wisdom of siri' napacce in carrying out their duties and responsibilities as village officials in Pacellekang Village, Pattallassang District, Gowa Regency.This research is a qualitative research with an ethnographic approach. The data source of this study is primary data in the form of direct interviews to several informants and subjects in the form of data from the research location. Furthermore, the data collection methods used were in-depth interviews, documentation and recording. Then, data processing and analysis techniques are qualitative analysis by building conclusions with the stages of data collection, triangulation data analysis and final conclusions. The results of this study indicate that the supervision of ADD management in Pacellekang Village is already good, in accordance with the principles of good governance. Starting at the planning stage, the implementation stage, and the accountability stage, the administration and financial management processes have been implemented in accordance with the principles of good governance, although there are still a few shortcomings. In addition, accountability and reporting are also direct to interested parties based on the cultural values of siri 'na pacce which can increase supervision of village fund allocation management (ADD) because as it is known that those who can participate in monitoring other than the community, the central government, are ourselves.
\end{abstract}

Keywords: Supervision, Honesty, Village Fund Allocation, Siri 'na Pacce

\begin{abstract}
Abstrak
Tujuan Penelitian ini adalah mengetahui korelasi antara good governance dan siri' napacce dalam mengawal realisasi dana desa serta mengetahui penerapan Budaya lokal siri' napacce dalam menjalankan tugas dan tanggung jawab sebagai aparatur desa di Desa Pacellekang Kecamatan Pattallassang Kabupaten Gowa. Penelitian ini merupakan penelitian kualitatif dengan pendekatan etnografi. Adapun sumber data dari penelitian ini adalah data primer berupa wawancara lansung kebeberapa informan dan subjek berupa data-data dari lokasi penelitian. Selanjutnya metode pengumpulan data yang digunakan adalah wawancara mendalam, dokumentasi dan perekaman. Lalu, teknik pengolahan dan analisis data yaitu analisis kualitatif dengan membangun kesimpulan dengan tahapan pengumpulan data, analisis data triangulasi dan penyimpulan akhir. Hasil penelitian ini menunjukkan pengawasan pengelolaan ADD di Desa Pacellekang terbilang sudah bagus, sesuai dengan prinsip good governance. Dimulai pada tahap perencanaan, tahap pelaksanaan, dan tahap pertanggungjawaban telah menerapkan proses pengelolaan administrasi dan keuangan yang sudah sesuai dengan prinsip good governance meskipun masih ada sedikit kekurangan. Selain itu pertanggungjawaban dan pelaporan juga langsung kepada pihak-pihak yang berkepentingan dengan berlandaskan pada nilai budaya siri' na pacce yang dapat meningkatkan pengawasan pengelolaan alokasi dana desa (ADD) karena sebagaimana diketahui bahwa yang dapat ikut dalam melakukan pengawasan selain masyarakat, pemerintah pusat, adalah diri kita sendiri.
\end{abstract}

Kata Kunci : Pengawasan, Kejujuran, Alokasi Dana Desa, Siri' na Pacce. 


\section{PENDAhUluaN}

Desa sebagai pemerintahan yang langsung bersentuhan dengan masyarakat menjadi fokus utama dalam pembangunan pemerintah, hal ini dikarenakan sebagian besar wilayah Indonesia ada di pedesaan (Alvianty dkk, 2013). Desa juga sebagai pemerintahan terkecil yang menuntut adanya pembaharuan dalam mendukung pembangunan desa dan tingkat kehidupan masyarakat yang jauh dari kemiskinan. Dalam pembangunan desa, pemerintahan desa berkedudukan sebagai subsistem dari sistem penyelenggaraan pemerintahan di Indonesia, sehingga desa memiliki kewenangan, tugas dan kewajiban untuk mengatur dan mengurus kepentingan masyarakatnya sendiri. Untuk menyelengarakan kewenangan, tugas, dan kewajiban desa dalam penyelenggaraan pemerintahan maupun pembangunan maka dibutuhkan sumber pendapatan desa (Kartika, 2012).

Beberapa hal yang menyebabkan desa membutuhkan sumber pendapatan yaitu: 1) Desa memiliki Anggaran Pendapatan dan Belanja Desa (APBDes) yang kecil dan sumber pendapatannya sangat bergantung pada bantuan yang sangat kecil pula. 2) Kesenjahteraan masyarakat desa yang rendah sehingga sulit bagi desa mempunyai Pendapatan Asli Desa (PADes) yang tinggi. 3) Masalah itu diikuti dengan rendahnya dana operasional desa untuk menjalankan pelayanan publik. 4) Banyak program pembangunan masuk ke desa akan tetapi hanya dikelola oleh dinas. Program semacam itu mendulang kritikan karena program tersebut tidak memberikan akses pembelajaran bagi desa, dan program itu bersifat top down sehingga tidak sejalan dengan kebutuhan desa dan masyarakatnya.

Menanggapi permasalahan tersebut, pemerintah memberi dukungan keuangan kepada desa salah satunya adalah berasal dari dana Perimbangan Keuangan antara Pemerintah Pusat dan Pemerintah Daerah minimal 10\% diperuntukkan bagi desa yang disebut Alokasi Dana Desa (ADD). Maksud pemberian ADD sebenarnya adalah sebagai bantuan stimulan atau dana perangsang untuk mendorong dalam membiayai program pemerintah desa yang ditunjang dengan partisipasi swadaya gotong royong masyarakat dalam melaksanakan kegiatan pemerintahan dan pemberdayaan masyarakat (Randa, 2015).

Dana desa bertujuan untuk meningkatkan kesejahteraan masyarakat desa dan adanya pemerataan dalam pembangunan yang dilaksanakan di desa dengan pelayanan kepada publik yang meningkat, perekonomian desa yang maju, mengurangi kesenjangan pembangunan antardesa, serta memperkuat masyarakat desa tidak hanya sebagai objek tapi bertindak sebagai subjek dalam pembangunan (Republik Indonesia, 2014). Berdasarkan Peraturan Pemerintah Nomor 60/2014, prioritas pemanfaatan dana desa adalah untuk pembangunan dan pemberdayaan masyarakat pedesaan. Desa mempunyai peran untuk mengurusi serta mengatur sesuai dengan Undang-Undang Nomor 6 Tahun 2014 tentang desa yang salah satu pasalnya dijelaskan bahwa desa memiliki kewenangan dalam bidang penyelenggaraan pemerintahan, pembangunan, pembinaan kemasyarakatan dan pemberdayaan desa. Selain itu pemberlakuan UndangUndang desa menetapkan entitas desa sebagai entitas pelaporan. Entitas desa 
memiliki kewenangan yang lebih besar dalam hal belanja termasuk kewenangan untuk membentuk badan usaha desa (Junaidi, 2015).

Pengelolaan keuangan dalam pembangunan baik di tingkat pusat ataupun tingkat daerah merupakan kunci penting dalam menunjang pelaksanaan pembangunan (Verasvera 2016). Namun dalam hal ini sering terdapat masalah yang dapat menghambat lajunya pembangunan, seperti yang kita ketahui hambatan justru sering dialami oleh daerah-daerah yang kurang potensial, baik itu sumber daya alamnya maupun sumber daya manusianya (Simon dkk, 2016).

Seiring dengan besarnya dana yang diberikan ke desa oleh pemerintah saat ini tentu saja menuntut ketelitian aparatur desa dalam pengelolaan keuangannya, agar yang menjadi harapan pemerintah, masyarakat, dan desa dapat tercapai. Sejak tahun 2015 hingga 2019 pemerintah telah mengalokasikan dana sebesar Rp257 triliun untuk dana desa. Adapun menurut Yabbar \& Hamzah (2017) dana desa yang berjumlah besar membutuhkan pengawasan sehingga dalam pengelolaannya harus sesuai dengan tujuan akhir yang telah ditetapkan serta yang telah diamanatkan. Sardjito dan Muthaher (2007).

Pengelolaan keuangan desa, dibutuhkan akuntansi pemerintahan yang baik di mana merupakan salah satu bidang ilmu yang sangat penting, dalam tulisan Kartika (2012), Thomas (2013), Mahfudz (2009) bahwa dalam proses pengelolaan Alokasi Dana Desa (ADD) harus dengan prinsip transparansi, akuntabilitas, dan partisipasi terhadap publik atas dana masyarakat yang dikelola pemerintah. Dalam hal ini lebih berfokus pada prinsip good governance.
Dalam literatur ilmu pemerintahan atau ilmu hukum istilah "tata kelola pemerintahan yang baik" sering pula disebut atau dipadankan dengan istilah "good governance". Kedua istilah ini seringkali saling dipergunakan secara silih arti (interchangeable), namun untuk maksud dan tujuan yang sama. Oleh karena itu, dalam tulisan ini istilah "tata kelola pemerintahan yang baik" dipersamakan dengan istilah "good governance". Nomenclatur "good governance" merupakan istilah yang telah tumbuh dan berkembang sejak lama baik dalam tataran internasional maupun nasional. Terselenggaranya suatu pemerintah daerah yang baik sebagai upaya mewujudkan good governance yang ditandai adanya tiga pilar utama, transparansi, partisipasi dan akuntabilitas, untuk itu maka perlu adanya penerapan dan pertanggungjawaban yang tepat, jelas dan nyata sehingga penyelenggaraan pemerintah dan pembangunan dapat berlangsung secara berdaya guna dan berhasil guna.

Upaya pemerintah untuk memajukan desa dan melakukan pemerataan pembangunan tidak serta merta berjalan mulus ada-ada saja oknum orang-orang yang tidak bertanggungjawab yang menyalah gunakan wewenang dan jabatannya untuk memperkaya diri sendiri atau kelompok-kelompok tertentu. Badan Pengawas Keuangan (BPK) mengungkapkan adanya permasalahan disebabkan oleh pengetahuan perangkat desa yang sangat minim, terutama jika tidak diikuti oleh pengawasan dan pendampingan yang maksimal dalam pengelolaan dan pelaporan keuangannya. Hal ini tentu saja dapat mengakibatkan terjadinya penyimpangan atau korupsi (Andoh, 
Quaye, \& Akomea \& Salin, 2016; Yenkey, 2018).

Terkuaknya kasus korupsi alokasi dana desa oleh KPK sepertinya semakin menyayat rasa keadilan masyarakat, dana untuk masyarakat miskin di pedesaan masih menjadi objek korupsi para aparat, lalu kenapa hal itu masih terjadi apakah masih ada yang kurang dari sisi pengawasan dan pencegahan? Lembaga Anti Corruption Commitee (ACC) Sulawesi menilai tren kasus korupsi di Sulawesi Selatan (Sulsel) hingga saat ini masih cukup tinggi. Hal itu dilihat dari jumlah kasus korupsi, dugaan kasus korupsi ditangani kepolisian dan kejaksaan selama satu tahun terakhir. Berdasarkan catatan ACC selama 2019, jumlah kasus dugaan korupsi ditangani di jajaran Kepolisian Daerah dan Kejaksaan Tinggi Sulsel mencapai 132 kasus (narasi.com).

Sejak 10 tahun terakhir era reformasi birokrasi, perang terhadap korupsi terus dilakukan. Mulai dari tingkat ekskutif, legislatif maupun yudikatif korupsi terus diberantas. Peran Komisi Pemberantasan Korupsi (KPK) mengalami berbagai fase perjuangannya dalam menaklukan korupsi. Pemberantasan korupsi yang dilakukan oleh KPK mengalami berbagai peningkatan yang signifikan. Peran KPK dalam pemberantasan korupsi mempunyai signifikasi yang sangat kuat terhadap pola pemberantasannya. Disamping itu, sanksi dan efek jera bagi pelaku korupsi terus di up to date. Hal ini sebagai upaya penanganan korupsi yang lebih efektif dan efisien (Hayat, Mar'atul Makhmudah, 2016).

Penelitian ini dilakukan dengan melihat komitmen dari perspektif Budaya lokal Makassar. Di mana penyelewengan atau kecurangan yang dilakukan terhadap pengelolaan dana desa tersebut disebabkan oleh lemahnya faktor mental atau psikologis yang bersumber dari nilainilai instrumental yang dianut sehingga mengakibatkan kecenderungan untuk berpikir singkat melalui jalan pintas (Munidewi, 2017). Nilai-nilai yang digali dalam penelitian ini dilihat dari dimensi psikologis yaitu dalam hal memperkuat pembangunan moral bangsa sehingga seorang individu akan berpikir untuk melakukan perbuatan yang sepatutnya (Nirban, 2018).

Punna teai kau ampatanjengi teako allei anjo kayu ripatanjenga, punna teai barangnu teako allei, punna teai kau antattaki teako allei anjo kayu lekbaka ri tatta ujunna. Makna dari pappasang tersebutmenyiratkan me ngenai ajaran untuk menghormati hak orang lain di samping mengetahui hak sendiri. Pappasang ini diungkapkan untuk mengingatkan masyarakat Makassar agar selalu menghormati hak orang lain. Pappasang tersebut merupakan perwujudan dari nilai kejujuran. Kejujuran tidak boleh dianggap biasa, bahkan disepelekan dalam kehidupan masyarakat Makassar. Kejujuran hendaknya senantiasa dilestarikan dan diaplikasikan dalam kehidupan sehari-hari. Salah satu penyebab terjadinya ketidak seimbangan dalam masyarakat adalah tidak diaplikasikannya nilai-nilai kejujuran itu. Padahal berlaku jujur merupakan suatu keharusan bagi setiap individu (Machmud, 1996: 15).

Perbaikan suatu bangsa haruslah diawali dari perbaikan budaya, dan perbaikan suatu budaya diawali dari perbaikan suatu mindset. Olehnya itu, setiap tulisan yang mengkaji tentang nilai-nilai budaya masyarakat lokal haruslah dipandang sebagai upaya untuk 
menyelamatkan bangsa dan generasi kita dari krisis identitas dan kehilangan jati dirinya (Anita, 2019). Upaya memasukkan nilai-nilai budaya ke dalam kajian akuntansi merupakan suatu bentuk perlawanan dengan dua tujuan. Pertama, agar akuntansi dapat mengakomodir kepentingan ekonomi masyarakat Indonesia, dalam artian akuntansi tidak hanya menjadi pelayan bangsa asing, namun juga menjadi pelayan bangsa sendiri. Kedua, agar setiap individu-individu yang menjadi pelaku akuntansi mempunyai moralitas yang didasarkan pada nilai-nilai transendental yang berakar dari nilai dan norma budaya yang sudah ada sejak zaman nenek moyang namun mulai terkikis oleh budaya asing (Anita, 2019:2).

Budaya sangat mempengaruhi perilaku individu, dan pada tataran individual budaya memberi pengaruh pada kehidupan individu lebih dari sekedar perilaku semata. Dalam praktiknya, norma-norma sosial senantiasa dijadikan pegangan, pedoman maupun indikator dalam menilai perilaku individu atau kelompok dalam komunitasnya. Norma tersebut mengandung nilai-nilai kearifan dari suatu budaya lokal. Kearifan budaya lokal merupakan pengetahuan lokal yang digunakan masyarakat untuk bertahan hidup dalam suatu lingkungan, sehingga dapat menyatu dengan sistem kepercayaan, norma, budaya dan diekspresikan di dalam tradisi dan mitos yang dianut dalam jangka waktu yang lama (Thontowi 2007).

Seperti halnya dalam Sylvia (2014) mengemukakan bahwa akuntansi sebagaimana bagian dari ilmu sosial yang dibentuk oleh manusia, mempunyai keterkaitan dan pengaruh dari keberadaan manusia itu di dalam suatu kelompok masyarakat. Sehingga nilainilai dalam budaya masyarakat tersebut turut serta dalam mempengaruhi pembentukan karekter ilmu akuntansi. Dengan kata lain, akuntansi dibentuk oleh lingkungannya melalui interaksi sosial yang sangat kompleks.

Sebagai perkembangan dari salah satu ilmu sosial, akuntansi saat ini sudah mengalami pergeseran nilai yang sangat berarti dan mendasar, sehingga pada kerangka teori yang mendasari akan akuntansi tersebut telah mengalami perubahan untuk mengikuti apa yang terjadi di dalam kehidupan masyarakat.

Selama ini yang digunakan sebagai dasar kontruksi teori akuntansi lahir dari konteks budaya dan idiologi (Karim 1990). Tricker (1978) dalam Triyuwono (2009) menyebutkan akuntansi adalah anak budaya masyarakat di mana akuntansi itu dipraktikkan. Pernyataan tersebut telah mengungkapkan bahwa konsep-konsep dari pemikiran manusia pada dasarnya merupakan hasil perpaduan antara cipta, rasa dan karsa manusia sehingga tercipta akuntansi yang merupakan sebuah produk budaya atau sosial. Lebih lanjut Hopwood (1994) dalam Wiyarni (2013) menjelaskan bahwa akuntansi bukan merupakan karunia yang secara otomatis menjadi sesuatu yang sangat signifikan sebagaimana yang tampak di mata publik saat ini.

Dalam penelitian ini coba dianalisis dengan menggunakan nilai budaya lokal Makassar. Masyarakat Makassar menjadikan siri' na pacce sebagai pegangan atau falsafah hidupannya yang tertuang dalam sistem sosial. Falsafah tersebut sebagai dasar pijakan hidup orang Makassar, yang banyak dipengaruhi oleh syariah islam sebagai 
agama yang dianut oleh kebanyakan masyarakatnya. Falsafah hidup masyarakat Makassar inilah yang syarat dengan nilai-nilai positif, budaya siri' na pacce adalah salah satu prinsip atau pegangan hidup masyarakat Makassar khususnya yang berdomisili di Kabupaten Gowa kecamatan Pattallassang desa Pacellekang.

Dahulu desa Pacellekang merupakan salah satu wilayah bagian dari kerajaan Gowa, yang dipimpin oleh seorang Gallarrang, yakni "' Gallarrang Pacellekang". Pada saat itu ada beberapa Tubarani yang direkrut dari daerah tersebut. Tubarani itu kemudian berada dalam suatu kelompok yang bernama desa Pacellekang yang dibentuk oleh distrik Pattallassang yang waktu itu di jabat oleh Abd. Rahim Daeng Tiro setelah diadakan Pemilihan Kepala desa (Pilkades I) pada tahun 1965 dan distrik Pattallassang bergabung dengan kecamatan Bontomarannu. Kecamatan Bontomarannu dimekarkan sebagian wilayahnya menjadi kecamatan Pattallassang. Pada waktu itu desa Pacellekang memiliki 3 Dusun antara lain: Dusun Pa'bundukang, dusun Pattiro dan dusun Bangkala.

Penelitian ini menggunakan metode Etnografi sebagai cara untuk melihat kajian tentang kehidupan dan kebudayaan suatu masyarakat atau etnik, misalnya tentang adat istiadat, kebiasaan, ekonomi, hukum, seni, religi dan bahasa untuk mencapai tujuan penelitian yang telah ditetapkan. Wolcott (1977) menjelaskan, etnografi adalah suatu metode khusus atau satu set metode yang di dalamnya terdapat berbagai bentuk yang mempunyai karakteristik tertentu, termasuk partisipasi etnografer, memahami dan mengikuti kehidupan sehari-hari dari seseorang dalam periode yang lama, melihat apa yang terjadi, mendengarkan apa yang dikatakan, bertanya kepada mereka, dan pada kenyataannya mengumpulkan data apa saja yang ada.

Dengan menggunakan pendekatan etnografi, penelitian ini berupaya untuk menguak lebih dalam mengenai pengawasan anggaran yang ditinjau berbasis Budaya lokal Makassar sebagai perwujudan nilai-nilai luhur masyarakat lokal.

Berdasarkan uraian di atas, maka peneliti tertarik untuk meneliti mengenai "Pengawasan Anggaran Ditinjau Dari Budaya Lokal Makassar Dalam Konsep Good Governance".

\section{TINJAUAN PUSTAKA}

\subsection{Teori Orientasi Nilai Budaya (Orientation Value of Culture Theory)}

Menurut seorang ahli antropologi terkenal yaitu Kluckhohn (Koentjaraningrat, 2009:154-155) bahwa setiap sistem nilai budaya dalam tiap kebudayaan mengandung lima masalah dasar dalam kehidupan manusia. Kelima masalah dasar dalam kehidupan manusia yang menjadi landasan bagi kerangka variasi sitem nilai budaya adalah sebagai berikut:

1. Masalah hakikat dari hidup manusia (selanjutnya disingkat $\mathrm{MH}$ ),

2. Masalah hakikat dari karya manusia (selanjutnya disingkat MK),

3. Masalah hakikat dari kedudukan manusia dalam ruang waktu (selanjutnya disingkat MW),

4. Masalah hakikat dari hubungan manusia dengan alam sekitarnya (selanjutnya disingkat MA),

5. Masalah hakikat dari hubungan manusia dengan sesamanya (MM). 


\subsection{Teori GONE (GONE Theory)}

Teori yang dikemukakan oleh Jack Bologna dalam Karyono (2013) dalam buku Strategi Pemberantasan Korupsi Nasional oleh BPKP Tahun 1999. Terdapat empat faktor pendorong seseorang untuk melakukan tindakan kecurangan, atau yang lebih dikenal sebagai teori GONE, yaitu:

1. Greed (Keserakahan) berkaitan dengan perilaku serakah yang potensial ada dalam diri setiap orang.

2. Opportunity (Kesempatan) berkaitan dengan keadaan organisasi, instansi, masyarakat yang sedemikian rupa sehingga terbuka bagi seseorang untuk melakukan kecurangan terhadapnya. Perceived Opportunity Pressure Rationalized Fraud Triangle.

3. Need (Kebutuhan) berkaitan dengan faktor-faktor yang dibutuhkan oleh individu untuk menunjang hidupnya secara wajar.

4. Exposure (Pengungkapan) berkaitan dengan kemungkinan dapat diungkapnya suatu kecurangan dan sifat serta beratnya hukuman terhadap pelaku kecurangan. Semakin besar kemungkinan suatu kecurangan dapat diungkap, semakin kecil dorongan seseorang untuk melakukan kecurangan tersebut, semakin berat hukuman kepada pelaku kecurangan akan semakin kurang dorongan seseorang untuk melakukan kecurangan.

\subsection{Anggaran}

Anggaran adalah suatu rencana kuantitatif (satuan jumlah) periodik yang disusun berdasarkan program yang telah disahkan. Anggaran (budget) merupakan rencana tertulis mengenai kegiatan suatu organisasi yang dinyatakan secara kuantitatif untuk jangka waktu tertentu dan umumnya dinyatakan dalam satuan uang, tetapi dapat juga dinyatakan dalam sautuan barang/jasa. Anggaran merupakan alat manajemen dalam mencapai tujuan. Jadi, anggaran bukan tujuan dan tidak dapat menggantikan manajemen (Latif, 2013). Dalam penyusunan anggaran perlu dipertimbangkan faktor-faktor sebagai berikut:

1. Pengetahuan tentang tujuan dan kebijakan umum perusahaan.

2. Data masa lalu.

3. Kemungkinan perkembangan kondisi ekonomi.

4. Pengetahuan tentang taktik, strategi pesaing, dan gerak-gerik pesaing.

5. Kemungkinan adanya perubahan kebijakan pemerintah.

6. Penelitian untuk pengembangan perusahaan.

\subsection{Alokasi Dana Desa}

\section{a. Pengelolaan Dana Desa}

Berdasarkan PP No 47 tahun 2015 tentang peraturan pelaksanaan UU No 6 tahun 2014 tentang desa yaitu: dana desa adalah dana yang bersumber dari anggaran pendapatan dan belanja negara yang diperuntukkan bagi desa yang ditransfer melalui anggaran pendapatan dan belanja daerah kabupaten/kota dan digunakan untuk membiayai penyelenggaraan pemerintahan, serta melakukan pelaksanaan pembangunan, pembinaan kemasyarakatan, dan pemberdayaan masyarakat. PP No. 60 Tahun 2014 ini kemudian direvisi kembali melalui PP No. 22 Tahun 2015. Substansi yang dirubah dalam PP No. 60 Tahun 2014 ke PP No. 22 Tahun 2015 adalah pada formula alokasi atau pembagian dana desa dari pusat ke kabupaten dan dari kabupaten ke desa.

Berdasarkan dari pengertianpengertian di atas dapat ditarik 
kesimpulannya bahwa pengelolaan dana desa adalah dana yang bersumber dari anggaran pendapatan dan belanja negara yang dipergunakan untuk pembangunan desa dan sebagai pendapatan desa.

\section{b. Perencanaan}

Mekanisme perencanaan menurut Permendagri No 113 Tahun 2014 adalah sebagai berikut:

1. Sekretaris desa menyusun Rancangan Peraturan Desa tentang APBDes berdasarkan RKPDesa. Kemudian Sekretaris Desa menyampaikan kepada kepala desa.

2. Rancangan Peraturan Desa tentang APBDes disampaikan kepala desa kepada Badan Permusyawaratan Desa untuk pembahasan lebih lanjut.

3. Rancangan tersebut kemudian disepakati bersama, dan kesepakatan tersebut paling lama bulan oktober tahun berjalan.

4. Rancangan Peraturan Desa tentang APBDes yang telah disepakati bersama, kemudian disampaikan oleh kepala desa kepada bupati/wali kota melalui camat atau sebutan lain paling lambat tiga hari sejak disepakati untuk dievaluasi. Bupati/wali kota dapat mendelegasikan evaluasi Rancangan Peraturan Desa tentang APBDes kepada camat atau sebutan lain.

5. Bupati/wali kota menetapkan hasil evaluasi Rancangan APBDes paling lama 20 hari kerja sejak diterimanya Rancangan Peraturan Desa tentang APBDes. Jika dalam waktu 20 hari kerja bupati/wali kota tidak memberikan hasil evaluasi maka peraturan desa tersebut berlaku dengan sendirinya.

6. Jika kepala desa melakukan penyempurnaan paling lama 7 hari kerja terhitung sejak diterimanya hasil evaluasi.

7. Apabila bupati/wali kota menyatakan hasil evaluasi Rancangan Peraturan Desa tentang APBDes tidak sesuai dengan kepentingan umum dan peraturan perundang-undangan yang lebih tinggi, maka kepala desa melakukan penyempurnaan paling lama 7 hari kerja terhitung sejak diterimanya hasil evaluasi.

8. Apabila hasil evaluasi tidak ditindaklanjuti oleh kepala desa dan kepala desa tetap menetapkan Rancangan Peraturan Desa tentang APBDes menjadi peraturan desa, bupati/wali kota membatalkan peraturan desa dengan keputusan bupati/wali kota.

9. Pembatalan peraturan desa, sekaligus menyatakan berlakunya pagu APBDes tahun anggaran sebelumnya. Dalam hal pembatalan, kepala desa hanya dapat melakukan pengeluaran terhadap operasional penyelenggaraan pemerintah desa.

10. Kepala desa memberhentikan pelaksanaan peraturan desa paling lama 7 hari kerja setelah pembatalan dan selanjutnya kepala desa bersama BPD mencabut peraturan desa dimaksud.

Berdasarkan dari pengertianpengertian di atas dapat ditarik kesimpulannya bahwa perencanaan adalah suatu proses dalam penentuan tujuan organisasi untuk mempermudah agar tercapainya sebuah tujuan dan langkah-langkah yang ingin dicapai.

\section{c. Pelaksanaan}

Terdapat beberapa aturan dalam pelaksanaan pengelolaan keuangan desa: 
1. Pemerintah desa dilarang melakukan pungutan sebagai penerimaan desa selain yang ditetapkan dalam peraturan desa.

2. Bendahara dapat menyimpan uang dalam kas desa pada jumlah tertentu dalam rangka memenuhi kebutuhan operasional pemerintah desa.

3. Pengaturan jumlah uang dalam kas desa ditetapkan dalam peraturan bupati/wali kota.

4. Pengeluaran desa yang mengakibatkan beban pada APBDes tidak dapat dilakukan sebelum rancangan peraturan desa tentang APBDes ditetapkan menjadi peraturan desa.

5. Pengeluaran desa tidak termasuk untuk belanja pegawai yang bersifat mengikat dan operasional perkantoran yang ditetapkan dalam peraturan kepala desa.

6. Penggunaan biaya tak terduga terlebih dahulu harus dibuat rincian anggaran biaya yang telah disahkan oleh kepala desa.

7. Pengadaan kegiatan yang mengajukan pendanaan untuk melaksanakan kegiatan harus disertai dengan dokumen antara lain Rencana Anggaran Biaya (RAB).

8. Rencana Anggaran Biaya diverifikasi oleh sekretaris desa dan disahkan oleh kepala desa.

9. Pelaksana kegiatan bertanggungjawab terhadap tindakan pengeluaran yang menyebabkan atas beban anggaran belanja kegiatan dengan mempergunakan buku pembantu kas kegiatan sebagai pertanggungjawaban pelaksanaan kegiatan desa.

10. Pelaksana kegiatan mengajukan Surat Permintaan Pembayaran (SPP) kepada kepala desa. Surat Permintaan Pembayaran (SPP) tidak boleh dilakukan sebelum barang dan atau jasa diterima. Pengajuan SPP terdiri atas Surat Permintaan Pembayaran (SPP), Pernyataan tanggungjawab belanja dan lampiran bukti transaksi.

11. Berdasarkan SPP yang diverifikasi sekretaris kepala desa kemudian kepala desa menyetujui permintaan pembayaran dan bendahara melakukan pembayaran.

12. Pembayaran yang telah dilakukan akan dicatat bendahara.

13. Bendahara desa sebagai wajib pungut Pajak Penghasilan (PPh) dan pajak lainnya, wajib menyetorkan seluruh penerimaan potongan dan pajak yang dipungutnya ke rekening kas negara sesuai dengan peraturan perundang-undangan.

Berdasarkan dari pengertianpengertian di atas dapat ditarik kesimpulannya bahwa pelaksanaan adalah sebuah rencana yang sudah disusun secara matang untuk mendapatkan hasil atau keinginan sesuai dengan yang diharapkan.

\section{d. Penatausahaan}

Menurut Permendangri No 113 Tahun 2014 laporan pertanggungjawaban yang wajib dibuat oleh bendahara desa adalah sebagai berikut:

1. Buku Kas Umum

Buku kas umum digunakan untuk mencatat berbagai aktifitas yang menyangkut penerimaan dan pengeluaran kas, baik secara tunai maupun kredit, digunakan juga untuk mencatat mutasi perbankan atau kesalahan dalam pembukuan. Buku kas 
umum dapat dikatakan sebagai sumber dokumen transaksi.

2. Buku Kas Pembantu Pajak

Buku pajak digunakan untuk membantu buku kas umum, dalam rangka penerimaan dan pengeluaran yang berhubungan denga pajak.

3. Buku Bank

Buku bank digunakan untuk membantu buku kas umum, dalam rangka penerimaan dan pengeluaran yang berhubungan dengan uang bank.

Berdasarkan dari pengertianpengertian di atas dapat ditarik kesimpulannya bahwa penatausahaan adalah pencatatan yang dilakukan oleh bendahara atas seluruh penerimaan dan pengeluaran yang dilakukan dan dicatat dalam buku kas umum yang bersifat tunai.

\section{e. Pelaporan}

Menyampaikan laporan pertanggungjawaban realisasi APBDes kepada bupati/wali kota berupa:

1. Laporan semester pertama berupa laporan realisasi APBDes, disampaikan paling lambat pada akhir bulan Juli tahun berjalan.

2. Laporan semester akhir tahun, disampaikan paling lambat pada akhir bulan Januari tahun berikutnya.

3. Menyampaikan Laporan Penyelenggaraan Pemerintahan Desa (LPPD) setiap akhir tahun anggaran kepada bupati/wali kota.

4. Menyampaikan Laporan Penyelenggaraan Pemerintahan Desa (LPPD) pada akhir masa jabatan kepada bupati/wali kota.

5. Menyampaikan laporan keterangan penyelenggaraan pemerintah desa.

Berdasarkan dari pengertianpengertian di atas dapat ditarik kesimpulannya bahwa pelaporan adalah suatu kegiatan penyampaian laporan yang dilakukan oleh bawahan kepada atasan sebagai hasil dari suatu pekerjaan yang dilakukan selama satu periode tertentu.

\section{f. Pertanggungjawaban}

Menurut Permendagri No 113 Tahun 2014 pertanggungjawaban terdiri dari:

1) Kepala desa menyampaikan laporan pertanggungjawaban realisasi pelaksanaan APBDes kepada bupati/wali kota melalui camat setiap akhir tahun anggaran. Laporan pertanggungjawaban pelaksanaan realisasi pelaksanaan APBDes terdiri dari pendapatan, belanja, dan pembiayaan. Laporan ini ditetapkan peraturan desa dan dilampiri:

a) Format laporan pertanggungjawaban realisasi pelaksanaan APBDes tahun anggaran berkenaan.

b) Format laporan kekayaan milik desa per 31 Desember tahun anggaran berkenaan.

c) Format laporan program pemerintah dan pemerintah daerah yang masuk ke desa.

2) Laporan pertanggungjawaban realisasi pelaksanaan APBDes sebagaimana dimaksud di atas, disampaiakan paling lambat 1 (satu) bulan setelah akhir tahun anggaran berkenaan.

Berdasarkan dari pengertianpengertian di atas dapat ditarik kesimpulannya bahwa pertanggungjawaban adalah suatu penyampaian yang dapat dipertanggungjawabkan pelaksanaannya yang tidak hanya disampaikan kepada pemerintah yang berwenang, tetapi harus disampaikan kepada masyarakat sebagai 
bukti bahwa laporan tersebut telah terealisasi dengan baik.

\subsection{Good Governance}

\section{a. Akuntabilitas}

Adapun berbagai jenis akuntabilitas publik menurut Adiwirya (2015) yaitu sebagai berikut:

1. Akuntabilitas Vertikal (Vertical Accountability)

Akuntabilitas Vertikal atau (Vertical Accountability) adalah pertanggungjawaban atas pengelolaan dana kepada otoritas yang lebih tinggi, misalnya pertanggungjawaban unit-unit kerja (dinas) kepada pemerintah daerah, pertanggungjawaban pemerintah daerah kepada pemerintah pusat, dan pertanggungjawaban pusat kepada MPR.

2. Akuntabilitas Horizontal (Horizontal Accountability)

Akuntabilitas Horizontal atau (Horizontal Accountability) adalah pertanggungjawaban kepada DPRD dan masyarakat luas. Dalam konteks organisasi pemerintah, akuntabilitas publik adalah pemberian informasi dan disclousure atas aktivitas dan kinerja finansial pemerintah kepada pihak-pihak yang berkepentingan dengan laporan tersebut.

\section{b. Transparansi}

Makna dari transparansi dalam penyelenggaraan pemerintahan daerah dapat dilihat dalam dua hal yaitu:

1. Salah satu wujud pertanggungjawaban pemerintah kepada rakyat, dan

2. Upaya peningkatan manajemen pengelolaan dan penyelenggaraan pemerintahan yang baik dan mengurangi kesempatan praktek kolusi, korupsi dan nepotisme (KKN).

prinsip transparansi pemerintahan dapat diukur melalui sejumlah indikator sebagai berikut:
1. Adanya sistem keterbukaan dan standarisasi yang jelas dan mudah dipahami dari semua proses-proses penyelenggaraan pemerintahan.

2. Adanya mekanisme yang memfasilitasi pertanyaan-pertanyaan publik tentang proses-proses dalam penyelenggaraan pemerintahan.

3. Adanya mekanisme pelaporan maupun penyebaran informasi penyimpangan tindakan aparat publik di dalam kegiatan penyelenggaraan pemerintahan.

\section{c. Partisipasi}

Ditinjau dari segi etimologis, kata partisipasi merupakan pinjaman dari bahasa Belanda "Participate" atau dari bahasa Inggris "Participation". Dalam bahasa latin disebut "Participatio" yang berasal dari kata kerja "Partipare" yang berarti ikut serta, sehingga partisipasi mengandung pengertian aktif yaitu adanya kegiatan atau aktivitas.

\section{d. Korupsi}

Korupsi berasal dari kata corruptus yang berarti perubahan tingkah laku dari baik menjadi buruk (to change ji-om good to bad in morals. manners. or actions): rot. spoil7 (rontok, rusak); dan lain-lain. Secara hukum, korupsi adalah "sebuah perbuatan yang dilakukan dengan maksud memberikan keuntungan yang tidak sesuai dengan tugas resmi dan hak orang lain" (an ael done H'ilh an intent to give sume advantage inconsistent with official dry and the right qorhers) 3 Pasal 2 ayat (I) UU No. 21 Tahun 1999 tentang Pemberantasan Tindak Pidana Korupsi menyebutkan bahwa orang yang dapat dipidana karena tindak pidana korupsi adalah "Setiap orang yang secara melawan hukum melakukan perbuatan memperkaya diri sendiri atau orang lain atau suatu korporasi yang dapat 
merugikan keuangan negara atau perekonomian negara (Ka'bah, 2007).

Unsur-unsur yang membentuk tindak pidana korupsi Pasal 2 ayat (1):

a. Memperkaya diri sendiri atau orang lain atau suatu korporasi

b. Secara melawan hukum menggambarkan suatu pengertian tentang sifat tercela atau sifat terlarangnya suatu perbuatan.

c. Merugikan keuangan negara atau perekonomian negara, tidak dijelaskan dalam penjelasan umum maupun penjelasan Pasal 2.

\subsection{Kearifan lokal di suku Makassar}

Dalam budaya Sulawesi Selatan (Bugis, Makassar) ada sebuah istilah atau semacam jargon yang mencerminkan identititas serta watak orang Sulawesi Selatan, yaitu Siri' $\mathrm{Na}$ Pacce. Secara lafdzhiyah Siri' berarti: rasa malu (harga diri), sedangkan Pacce atau dalam bahasa bugis disebut Pesse yang berarti: pedih/ pedas (keras, kokoh pendirian). Jadi Pacce berarti semacam kecerdasan emosional untuk turut merasakan kepedihan atau kesusahan individu lain dalam komunitas (solidaritas dan empati).

Pacce sebagai prinsip solidaritas dari individu Bugis Makassar dan menunjuk prinsip getteng, lempu, acca, warani (tegas, lurus, pintar, berani) sebagai empat ciri utama yang menentukan ada tidaknya Siri'. Siri' yang merupakan konsep kesadaran hukum dan falsafah masyarakat Bugis-Makassar adalah sesuatu yang dianggap sakral. Siri' na Pacce (bahasa Makassar) atau Siri' na Pesse' (bahasa Bugis) adalah dua kata yang tidak dapat dipisahkan dari karakter orang Bugis-Makassar dalam mengarungi kehidupan di dunia ini. Begitu sakralnya kata itu, sehingga apabila seseorang kehilangan Siri'nya atau De'ni gaga
Siri'na, maka tak ada lagi artinya dia menempuh kehidupan sebagai manusia. Bahkan orang Bugis-Makassar berpendapat kalau mereka itu sirupai olo' kolo'e (seperti binatang). Petuah Bugis berkata: Siri'mi Narituo (karena malu kita hidup).

Siri' adalah rasa malu yang terurai dalam dimensi-dimensi harkat dan martabat manusia, rasa dendam (dalam hal-hal yang berkaitan dengan kerangka pemulihan harga diri yang dipermalukan). Jadi Siri' adalah sesuatu yang tabu bagi masyarakat BugisMakassar dalam interaksi dengan orang lain. Sedangkan pacce/pesse merupakan konsep yang membuat suku ini mampu menjaga solidaritas kelompok dan mampu bertahan di perantauan serta disegani. Pacce merupakan sifat belas kasih dan perasaan menanggung beban dan penderitaan orang lain, meskipun berlainan suku dan ras. Jadi, kalau pepatah Indonesia mengatakan "Ringan sama dijinjing, berat sama dipikul". Itulah salah satu aplikasi dari kata pacce, jadi Siri' skopnya dalam skala intern, sedang pacce bersifat intern dan ekstern, sehingga berlaku untuk semua orang.

$\begin{array}{ccc}\text { Budaya } & \text { Siri' } \mathrm{Na} & \text { Pacce lebih } \\ \text { menuntut } & \text { agar } & \text { orang-orang }\end{array}$
menjalankan kewajibannya dengan sebaik-baiknya karena memiliki tanggungjawab sosial. Selain itu, dengan menjunjung tinggi harga diri dalam bekerja maka akan membuat individu lebih giat, amanah, serta mengaplikasikan nilai-nilai kejujuran. Apabila Siri' Na Pacce sebagai pandangan hidup tidak dimiliki oleh seseorang, maka akan dapat berakibat orang tersebut bertingkah laku seenaknya karena tidak memiliki unsur kepedulian sosial dan hanya mau menang sendiri. Menggali nilai budaya untuk penyusunan 
kebijakan adalah jalan yang tepat, sebagaimana pandangan yang dikemukakan oleh Eugen Elrich bahwa "hukum yang baik adalah hukum yang hidup dalam masyarakat (Gerhana dkk, 2019).

\section{METODE PENELITIAN}

\subsection{Teknik Analisis Data}

Menurut patton (dalam Moleong, 2006), analisis data merupakan proses mengatur data, mengorganisasikannya ke dalam suatu pola, kategori, dan satuan uraian dasar.

Analisis data dalam penelitian etnografi merupakan bagian dari alur penelitian maju bertahap. Alur penelitian maju bertahap adalah suatu proses yang dimulai dari menetapkan informan, hingga menulis sebuah etnografi (Spadley dalam Batuadji, 2009). Proses analisis data etnografis dimulai dari lapangan, yaitu dengan pembuatan catatan lapangan. Ada empat jenis catatan lapangan, yaitu catatan lapangan yang terbentuk:

a) laporan ringkas,

b) laporan diperluas,

c) jurnal penelitian lapangan, serta

d) catatan lapangan yang disertai analisis dan interpretasi. Langkah berikutnya adalah pencarian domain pendahuluan.

Analisis data dimulai dengan melakukan wawancara mendalam dengan partisipan setelah dilakukan observasi dan menentukan domain yang dihasilkan dari laporan observasi. Setelah melakukan wawancara kepada partisipan, analisis data dimulai dengan membuat transkip hasil wawancara, dengan cara memutar kembali rekaman hasil wawancara, mendengarkan dengan seksama, kemudian menuliskan kata-kata yang didengar sesuai dengan apa yang ada dalam rekaman tersebut. Setelah peneliti menulis hasil wawancara tersebut ke dalam transkip, selanjutnya peneliti harus membaca secara cermat untuk kemudian dilakukan reduksi data. Peneliti membuat reduksi data dengan cara membuat abstraksi, yaitu dengan mengambil dan mencatat informasiinformasi yang bermanfaat sesuai dengan konteks penelitian atau mengabaikan kata-kata yang tidak perlu sehingga didapatkan inti kalimatnya saja, tetapi bahasanya sesuai dengan bahasa partisipan.

\section{HASIL PENELITIAN}

\subsection{Penerapan Budaya Lokal Siri' Napacce dalam Menjalankan Tugas dan Tanggungjawab Sebagi Aparatur Desa}

Pelaksanaan akuntabilitas yang dimulai dari proses penganggaran kemudian dari perencanaan, penyusunan pelaksanaan harus benar-benar dapat dilaporkan dan dipertanggungjawabkan kepada masyarakat sesuai dengan kenyataan. Dari hasil ini sesuai dengan konsep kejujuran yang di mana masyarakat sebagai prinsipal memiliki hak untuk memperoleh pertanggungjawaban mengenai dana desa yang digunakan oleh pemerintah berdasarkan anggaran yang telah disusun. Yang mana akuntabilitas mensyaratkan bahwa pengambil keputusan berperilaku sesuai dengan mandat yang diterimanya sehingga pelaksanaan program-program pemerintahan dapat berjalan dengan baik. Sinclair mendefinisikan akuntabilitas sebagai perilaku individu atau organisasi untuk menjelaskan dan bertanggungjawab atas tindakannya melalui pemberian alasan mengapa tindakan dilakukan (Randa,2011). 
Definisi ini memandang bahwa setiap individu atau organisasi wajib menyampaikan pertanggungjawaban sebagai wujud akuntabilitas individu atau organisasi. Konsep ini mengingatkan setiap individu atau organisasi akan pentingnya akuntabilitas dibangun guna meningkatkan kepercayaan dan keberterimaan satu sama lain dalam organisasi baik itu pertanggungjawaban pemerintahan kepada masyarakat.

Dalam nilai budaya siri' na pacce menurut H. Rusdi terdapat sifat dasar yang menjadi prinsip utama dalam kehidupan masyarakat Makassar yang biasa disebut Lima Akkatenningeng (Marzuki, 1995: 40) yaitu :

\section{a. Lempu' (Kejujuran)}

Lempu' dalam bahasa Indonesia artinya jujur, sama dengan lurus sebagai lawan dari bengkok. Dalam berbagai konteks kata ini berarti ikhlas, benar, baik atau adil. Sehingga lawan katanya adalah culas, curang, dusta, khianat, seleweng, buruk, tipu, aniaya, dan semacamnya. Kejujuran (lempu') menjadi kunci utama dalam kepemimpinan. Seperti yang dikatakan oleh kepala desa bahwa:

" Apapun yang kita ucapkan harus ki sesuai dengan apa yang kita lakukan, karena yang mau kita lakukan ini bukan hal kecil tetapi menyangkut orang banyak khususnya kepada masyarakat desa Paccellekang".

Dari wawancara di atas dapat dipahami bahwa, seseorang yang diberi amanah harus jujur dalam berniat, bukan memaksakan kehendak untuk menerima suatu amanah yang sebenarnya tidak disanggupi. Kejujuran (Lempu') dalam berniat ini merupakan tahap awal dalam akuntabilitas, di mana pemerintah sebagai agen yang diberikan kepercayaan oleh masyarakat dapat berlaku jujur dalam menetapkan sebuah keputusan dan tidak menyalahgunakan anggaran yang diperuntukkan untuk rakyat.

Pada akuntabilitas kejujuran dikatakan bahwa akuntabilitas ini terkait dengan penyalah gunaan jabatan. Akuntabilitas ini sesuai dengan makna lempu pada budaya siri' na pacce yang artinya jujur. Dibutuhkannya kejujuran pemerintah desa sebagai pengayom masyarakat dalam menjalankan tugasnya.

Faktor komunikasi, toleransi dan dialog antar pemeluk agama merupakan kunci sukses untuk itu serta dialog yang berkelanjutan dan dilandasi adanya kejujuran di antara komponen masyarakat, terutama antar pemeluk agama. Dialog yang berkejujuran ini diharapkan dapat mengurai permasalahan yang selama ini mengganjal di benak masing-masing kelompok di masyarakat. Mungkin saja masalah yang selama ini terjadi di antara pemeluk agama, atau di antara pemeluk agama yang berbeda faham, muncul karena tidak sampainya informasi yang benar dari satu pihak ke pihak lainnya. Terputusnya jalinan informasi antar kelompok dalam mayarakat dapat menimbulkan prasangka - prasangka yang mengarah pada terbentuknya penilaian negatif. Oleh karenanya, dialog yang berkejujuran di antara komponen masyarakat, khususnya antar pemeluk agama, atau antar pemeluk agarna yang berbeda faham, mutlak diperlukan (Mashudi, 2014).

Mengenai lempu itu bisa kita lihat dari hasil kerja atau fisik yang ada. Jujur ki dan berkata benar ki kalo memang ada itu pembangunan. Dapat juga dari kualitas kerjanya, bahwa betul-betul ini kita lakukan pekerjaan itu. Betul-betul kita melakukan pekerjaan demi kualitas kerja.

Dari hasil wawancara di atas kepala desa menganggap bahwa lempu' 
dapat dilihat dari apa yang terjadi di masyarakat. Dilihat dari kualitas pekerjaan yang telah dilakukan oleh aparat. Dalam dimensi akuntabilitas kejujuran dikatakan bahwa akuntabilitas itu penghindaran dari penyalah gunaan jabatan, korupsi dan kolusi serta menjamin adanya praktik organisasi yang sehat (Manis, 2017). Lempu' dalam dimensi akuntabilitas kejujuran yaitu kejujuran dan kebijaksanaan yang menjadi kunci dalam memimpin. Kejujuran (Lempu') dalam berniat ini merupakan tahap awal dalam akuntabilitas, di mana pemerintah sebagai agen yang diberikan kepercayaan oleh masyarakat dapat berlaku jujur dalam menetapkan sebuah keputusan dan tidak menyalahgunakan dana yang diperuntukkan untuk masyarakat.

Sebagaimana

sebelumnya bahwa akuntabilitas pengelolaan alokasi dana desa dimaksudkan sebagai upaya untuk mewujudkan tata kelola pemerintahan yang baik. Nilai lempu' menjadi dimensi penguat dalam pelaksanaan akuntabilitas yang memiliki makna sangat dalam mengenai kejujuran. Seperti yang dikatakan oleh kepala desa bahwa :

Kalo lempu' atau jujur itu sangat dalam maknanya, haruski benar-benar terbuka kepada masyarakat. Mulai dari perencanaan sampai pada pertanggungjawaban kita kepada masyarakat itu harus benar sesuai dengan apa yang kita lakukan, tidak boleh ki berbohong karena ini menyangkut orang banyak".

Para ahli Tasawuf, mengartikan jujur itu sebagai keseimbangan antara lahir dan batin, antara berbuat dan berkehendak yakni perbuatannya tidak berlawanan dengan amalnya dan amalnya tidak berlawanan dengan perbuatannya (Midong dan Aisyah, 2010:63-64). Hal ini senada dengan apa yang dikatakan oleh Arifin Nukman.S.Kom bendahara bahwa:

"Jujur itu tidak hanya tentang apa yang dikatakan, tapi harus ki juga jujur sama niat ta. Mengenai ini ADD itu harus jujur dari perencanaan sampai pertanggungjawabannya. Karena bukan cuma berdampak sama orang lain tapi juga sama kita, berdosa ki kalo tidak jujur $k i$.

Ungkapan di atas menggambarkan konsep jujur bagi masyarakat Bugis-Makassar yang menjadi sebuah nilai kesadaran "imani", dimulai dari suara hati, dan kualitas imannyalah yang mengantarkan seseorang menjadi jujur. Jadi, yang disebut dengan jujur adalah sebuah sikap yang selalu berupaya menyesuaikan atau mencocokkan antara informasi dengan fenomena atau realitas (Thaba, 20015). Dalam pandangan agama islam sikap seperti inilah yang dinamakan shiddiq dalam bahasa Bugis disebut malempu atau jujur. Dengan begitu, jujur itu bernilai tak terhingga.

\section{b. Ada' Tongeng (Berkata Benar)}

Ada' tongeng dalam bahasa Indonesia artinya berkata benar, kebenaran. Dalam KBBI kebenaran berasal dari kata benar yang artinya sesuai sebagaimana adanya (seharusnya), betul, tidak salah apa yang dikatakannya. Kebenaran adalah keadaan (hal dan sebagainya) yang cocok dengan keadaan (hal) yang sesungguhnya. Ada' tongeng (kata-kata yang benar) maksudnya agar manusia berpegang pada ada' tongeng, melakukan perbuatan sesuai apa yang diucapkan. Dana itu tersalur dengan baik sesuai dengan peruntukan, bisa dibuktikan dengan beberapa fisik yang telah dikerjakan bahwa itu benar-benar 
ada. Bisa juga kita buktikan dengan laporan-laporan yang ada, bahwa benar apa yang telah ditulis dengan yang terealisasi.

Dari pernyataan di atas bahwa pelaksanaan kegiatan pengelolaan ADD sesuai dengan ada' tongeng (kebenaran). Di mana Ada' tongeng adalah sebuah nilai yang berfungsi untuk menjaga kebenaran, kevalidan dan keandalan dalam melaksanakan sesuatu (Prawono, 2017). Sehingga aktualisasi ada tongeng dalam dipandang perlu sebagai kode perilaku bagi pemerintah. Dengan adanya ada' tongeng, pemerintah menjalankan pemerintahan sesuai dengan niat dan perbuatannya.

Kebenaran (ada' tongeng) adalah persesuaian antara pengetahuan dan objek bisa juga diartikan suatu pendapat atau perbuatan seseorang yg sesuai dengan (atau tidak ditolak oleh) orang lain dan tidak merugikan diri sendiri.

Dalam pengelolaan ADD ini kita berusaha untuk tidak merugikan orang lain, dan alhamdulillah berjalan dengan semestinya. Kita sampaikan informasi itu sesuai kenyataan bahwa memang benarbenar ada ki itu dianggaran, fisik dan laporannya. Ini jelas bahwa dalam melaksanakan pengelolaan ADD pemerintah harus menjalankan sesuai dengan kebenaran yang ada. Tidak menyembunyikan sesuatu apapun kepada aparat dan masyarakat. selain itu juga adanya larangan bagi pemerintah menggunakan dana yang diperuntukkan masyarakat tanpa tujuan yang tidak jelas, tidak sesuai dengan peruntukannya.

\subsection{Korelasi antara good governance dan siri' napacce dalam meningkatkan pengawasan anggaran dana desa}

Desa sebagai sistem pemerintahan terkecil menuntut adanya pembaharuan guna mendukung pembangunan desa yang lebih meningkat dan tingkat kehidupan masyarakat desa yang jauh dari kemisikinan (Kartika, 2012). Dalam menanggulangi hal ini pemerintah melakukan kebijakan dengan adanya otonomi daerah. Otonomi daerah adalah kewenangan daerah otonom untuk mengatur dan mengurus kepentingan masyarakat setempat menurut prakarsa sendiri berdasarkan aspirasi masyarakat sesuai dengan peraturan perundangundangan. Pemerintah pusat melalui otonomi daerah memberikan kewenangan kepada pemerintah daerah untuk mengatur dan mengurus sendiri pengelolaan pemerintahannya, namun tetap dengan dukungan penuh dari pemerintah pusat dalam pelaksanaannya.

Adapun bentuk otonomi daerah yaitu dengan pemberian dana perimbangan antara pemerintah pusat dengan pemerintah daerah kepada pemerintah desa yang disebut dengan Alokasi dana Desa (ADD). Alokasi dana desa menjadi bantuan stimultan atau dana perangsang untuk mendorong dalam membiayai program pemerintah desa yang ditunjang dengan partisipasi swadaya gotong royong masyarakat dalam melaksanakan kegiatan pemerintah dan pemberdayaan masyarakat. Sebagaimana yang dikatakan oleh bendahara Desa Paccellekang bahwa:

"ADD ini bagus sekali karena banyak yang bisa kita lakukan untuk pembangunan desa, ini dana kan tujuan utamanya untuk masyarakat. Jadi lebih banyak lagi pelatihan-pelatihan untuk masyarakat".

Dalam pelaksanaan pengelolaan alokasi dana desa perlunya diterapkan prinsip-prinsip good governance yaitu akuntabilitas, transparansi, dan partisipasi. Melalui tulisan ini maka akan 
dibahas mengenai prinsip Good Governance. Berdasarkan prinsip Good Governance pada sistem pengelolaan alokasi dana desa dimaksudkan sebagai upaya untuk mewujudkan tata kelola pemerintahan yang baik. Tingkat pertanggungjawaban dalam implementasi pengelolaan alokasi dana desa dimulai pada tahap perencanaan, pelaksanaan, penatausahaan, pelaporan dan pertanggungjawaban terhadap publik.

Dalam pelaksanaan pengawasan anggaran Alokasi Dana Desa atau ADD perlu dikolaborasikan dengan budaya lokal. Seperti pada masyarakat Bugis, Makassar dan Gowa yang memiliki budaya siri' na pacce. Di mana siri' na pacce merupakan suatu falsafah yang tidak dapat dipisahkan, karena antara satu dan yang lainnya mempunyai keterkaitan makna dan hubungan, sehingga dalam pembagian siri' na pacce keduanya saling berkaitan erat.

Salah satu syair orang Makassar yang sesuai dengan jenis siri' yaitu:

Takunjunga' bangunturu' nakugunciri' gulingku, kualleanna tallanga na toali'a artinya tidak begitu saja ikut angin buritan dan kemudian saya putar kemudiku, lebih baik tenggelam daripada balik haluan. Dalam hal ini bahwa pemerintah dalam melaksanakan tugasnya yang diberikan oleh masyarakat (prinsipal) meskipun ada banyak peluang untuk melakukan kecurangan dalam pengelolaan keuangan pemerintah desa atau yang sering disebut KKN, tidak akan pernah dilakukan karena adanya sifat siri'. Seperti pada wawancara oleh bapak Ibnu selaku tokoh masyarakat mengatakan bahwa:

"Kapan tidak sesuai dengan siri' na pacce maka saya melakukan pekerjaan asalasalan. Betul-betul itu siri' na pacce bukan hal yang main-main. Karena dalam sekali itu maknanya".

Seperti pada banyak kasus juga bahwa banyak pemimpin-pemimpin yang memiliki rasa tanggungjawab penuh terhadap masyarakat dihukum karena sifat siri' mereka mempertahankan apa yang mereka yakini meskipun dihukum. Ketika pemerintah (agen) telah bertekad untuk berbuat baik dan memperoleh kehidupan yang layak melalui perilaku jujur dan bertanggungjawab terhadap pihak yang memberikan amanah maka apapun rintangan yang menghadang akan tetap dihadapinya sampai keinginan mereka berhasil. Ketika suatu pihak tidak memiliki lagi sifat siri' na pacce maka akan menimbulkan hal-hal buruk, baik bagi dirinya, orang lain dan lingkungannya. Dalam kaitannya dengan pemerintahan salah satu raja cendikiawan di nusantara yang pada eranya, kerajaan Makassar (Gowa-Tallo) mencapai zaman keemasannya meninggalkan suatu teori yang meruntuhkan pemerintahan, yakni merumuskan 5 faktor penyebab runtuhnya pemerintahan yang meliputi:

- Punna tenamo na ero' nipakainga' karaeng manggauka (apabila pemerintah tidak mau dinasehati)

- Punna taenamo tumangngasseng ri lalang pa'rasanganta (apabila tidak adalagi cendikiawan/intelektual di dalam negeri)

- Punna majai gau' lompo ri lalang pa'rasanganga (apabila sudah terlampau banyak masalah dalam daerah)

- Punna angngalle ngasengmi soso' pabbicaraya (apabila banyak hakim dan pejabat pemerintahan suka makan sogok) 
- Punna taenamo nakamaseangi atanna manggauka (apabila pemerintah tidak lagi menyayangi rakyatnya).

Siri' sebagai rasa malu pemerintahan ketika melakukan kejahatan seperti sogok dan pacce yang berarti perih, kasihan ketika melihat warganya ada yang menderita dan merasakan kemiskinan. Pemerintah memiliki rasa tanggungjawab terhadap rakyatnya yang telah memberikan amanah kepadanya dalam menjalankan aspirasi mereka. Aspirasi yang telah disampaikan melalui musyawarah dengan melibatkan masyarakat yang sering disebut dengan musrenbangdes. Dalam musrenbangdes dilakukan perencanaan yang akan dilaksanakan selama satu periode. Yang kemudian direalisasikan melalui pembangunan desa dan pemberdayaan masyarakat sesuai dengan anggaran yang telah diatur yaitu 30\% untuk pelaksanaan operasi pemerintah dan BPD dan 70\% untuk pemberdayaan masyarakat. Yang di mana diperlukan pertanggungjawaban pemerintah dengan mentransformasi budaya lokal siri' na pacce yang menjadi falsafah masyarakat Makassar.

Siri' na pacce merupakan budaya yang telah melembaga dan dipercaya oleh suku Makassar dan Gowa yang dapat sejalan dengan ajaran islam, namun tergantung bagaimana upaya pemahaman masyarakat dalam penegakan siri' sesuai dengan tuntutan ajaran islam. Selain itu falsafah pacce yang berarti turut merasakan dan membantu orang yang mengalami penderitaan, karena manusia semuanya bersaudara. Hal ini sangat erat kaitannya dengan budaya siri' na pacce yang dianut oleh masyarakat Bugis Makassar. Siri' na pacce mengajarkan agar sesaman manusia harus memiliki rasa malu dan saling mengasihani.

Dikaitkan dengan pemerintahan, melalui filosofi siri' na pacce dapat memberikan pesan bahwa setiap pemimpin (agent) harus memiliki rasa malu dalam melaksanakan tanggungjawabnya. Dengan adanya rasa malu dapat membangun organisasi (pemerintah) dalam melaksanakan tata kelola pemerintahan yang baik (good governance). Seperti yang dikatakan oleh kepala desa bahwa :

"Siri' na pacce itu tidak boleh kita hiraukan, karena merupakan jati diri kita sebagai orang Makassar asli. Jadi dalam melaksanakan tugas kita sebagai pemerintah itu harus berlaku jujur dan adil. Kalau sifat itu sudah tidak ada maka akan hancurlah desa kita ini".

Siri' na pacce yang menjadi falsafah hidup yang menjiwai dan menjadi pegangan masyarakat Bugis-Makassar untuk senantiasa hidup baik di negeri sendiri atau negeri orang lain adalah menjadi manusia yang perkasa dalam menjalani kehidupan. Jadi setiap manusia keturunan Bugis-Makassar dituntut harus memiliki keberanian, pantang menyerah menghadapi tantangan ataupun ujian hidup. Itulah sebabnya maka setiap orang yang mengaku sebagai masyarakat BugisMakassar memiliki orientasi yang mampu menghadapi apapun. Hakekat prinsip tersebut bersumber pada leluhur masyarakat Bugis-Makassar yang tersimpul dalam "duai temmallaiseng, tellui temmasarang" (dua bagian yang tak terpisahkan dan tiga bagian yang tak terceraikan).

Di Desa Paccellekang pelaksanaan pengelolaan alokasi dana desa sudah sesuai dengan budaya siri' na pacce. Seperti yang dikatakan oleh kepala Desa Paccellekang yang menyatakan bahwa : 
"Akuntabilitas pengelolaan ADD di Desa Tanabangka itu sesuai dengan budaya siri' na pacce karena seperti artinya siri' itu malu, jadi malu-malu ki kalo yang menjadi haknya orang kita ambil. Dan pacce itu peduli, jadi peduliki sama masyarakatta yang membutuhkan. $N a$ ini $A D D$ itu uangnya masyarakat"

Berdasarkan beberapa hasil wawancara di atas pelaksanaan akuntabilitas di Desa Paccellekang sesuai dengan budaya siri' na pacce. Di mana prinsip Good Governance itu berhubungan dengan tanggungjawab dan kejujuran pemerintah dalam melaksanakan tugas dan wewenang yang di amanahkan oleh masyarakat. Hal ini sesuai dengan budaya siri' na pacce yang mana budaya siri' na pacce juga memiliki nilai lempu' (jujur) dan ada' tongeng (berkata benar) dalam melakukan suatu perbuatan.

Falsafah siri' na pacce yang sudah ada dan dipegang sejak dahulu oleh masyarakat Suku Makassar serta merupakan pandangan hidup yang perlu dipertahankan dan perlu diselaraskan dengan ajaran dan akidah islam. Ada ungkapan suku Makassar yang berbunyi punna tena siriknu, paccenu seng pakania (kalau tidak ada siri'-mu pacce-lah yang kau pegang teguh) (Limpo, 1995: 87). Ungkapan ini menggambarkan bahwa antara siri' dan pacce selalu seiring sebagai satu kesatuan yang tidak terpisahkan. Apabila siri' dan pacce sebagai pandangan hidup tidak dimiliki oleh seseorang, maka akan dapat berakibat orang tersebut bertingkah laku melebihi binatang (tidak punya malu/siri') karena tidak memiliki unsur kepedulian sosial dan hanya mau menang sendiri (tidak merasakan sedih/pacce). Hal ini menggambarkan bahwa sebagai pemerintah harus peduli kepada masyarakat. Seperti yang dikatakan oleh kepala desa bahwa:

"Kita itu sekarang melakukan pembangunan sesuai keinginannya masyarakat, meskipun biasa anggarannya belum keluar. Karena biasa itu kasian ki lihat masyarakat, kalo banjir ki batunya basai. Karena kan kita di Tanabangka itu pabatu banyak, jadi kalo banjir ki rusa ki batunya".

Berdasarkan hasil wawancara di atas menggambarkan bahwa ada rasa pacce yang dimiliki pemerintah terhadap masyarakatnya. Sebagaimana dalam Marzuki (1995:133) menyatakan bahwa pacce memotivasi solidaritas dalam penegakan harkat orang lain. Perasaan pacce dikala melihat orang lain menderita. Berdasarkan apa yang disampaikan oleh kepala desa maka bisa dikatakan bertentangan dengan budaya siri' na pacce yang menjunjung tinggi nilai kejujuran (Lempu') yang menjalankan tugas berdasarkan apa yang telah direncanakan. Akan tetapi menurut Leonard Y. Anandya dalam Marzuki (1995: 133) bahwa jika siri' belum kunjung dilaksanakan dengan maksimal maka setidaknya masih terdapat pacce yang dapat menjadi nilai positif.

Terdapat ungkapan pappasang orang Bugis-Makassar yaitu Ikambe Mangkasaraka, punna tena siri' pacce seng nipabbulo sibatangngi yang artinya manakala tiada lagi siri'(malu) maka masih terdapat pacce (peduli) yang mempersatukan kami. Pacce ini berfungsi sebagai alat penggalang persatuan, solidaritas, kebersamaan rasa kemanusiaan dan memberi motivasi pula untuk berusaha sekalipun dalam keadaan yang sangat pelik dan berbahaya (Limpo, 1995: 91).

Dalam nilai lempu' (kejujuran) seseorang yang diberi amanah harus jujur 
dalam berniat, bukan memaksakan kehendak untuk menerima suatu amanah yang sebenarnya tidak disanggupi. Kejujuran (Lempu') dalam berniat ini merupakan tahap awal dalam akuntabilitas, di mana pemerintah sebagai agen yang diberikan kepercayaan oleh masyarakat dapat berlaku jujur dalam menetapkan sebuah keputusan dan tidak menyalahgunakan anggaran yang diperuntukkan untuk rakyat. Dan dalam nilai ada' tongeng (berkata benar) sebagai sebuah nilai yang berfungsi untuk menjaga kebenaran, kevalidan dan ADD berdasarkan prinsip Good Governance dengan nilai budaya siri' na pacce :

\begin{tabular}{|l|l|}
\hline $\begin{array}{l}\text { Prinsip Good } \\
\text { Governance }\end{array}$ & $\begin{array}{l}\text { Nilai-Nilai } \\
\text { Budaya Siri' } \\
\text { Na Pacce }\end{array}$ \\
\hline Perencanaan ADD : & Lempu' \\
1. Transparansi & Ada' \\
2. Partisipasi & Tongeng \\
& Sipakatau \\
\hline Pelaksanaan ADD : & Sipakatau \\
1. Akuntabilitas & Lempu' \\
\hline
\end{tabular}

Dari berbagai uraian di atas sesuai dengan teori orientasi nilai budaya yang menjelaskan bahwa nilai-nilai yang terkandung dalam budaya sangatlah beragam, dan dalam nilai-nilai budaya tersebut ada nilai-nilai kebaikan yang perlu diikuti oleh masyarakat Indonesia serta dapat dijadikan sebagai kontrol, dan pedoman hidup masyarakat dan adapula yang tidak perlu diikuti oleh masyarakat. Seperti yang dikatakan oleh bapak kepala Desa Paccellekang bahwa :

"Nilai siri' na pacce ini tidak boleh kita tingalkan, karena ini menjadi harga diri ta sebagai masyarakat Gowa. Karena ini siri' na pacce warisan leluhur ta yang memang nilai-nilai di dalamnya itu syarat akan makna" keandalan dalam melaksanakan sesuatu (Prawono, 2017). Sehingga aktualisasi ada tongeng dalam dipandang perlu sebagai kode perilaku bagi pemerintah.

Dengan adanya ada' tongeng pemerintah menjalankan pemerintahan sesuai dengan niat dan perbuatannya. Kebenaran (ada' tongeng) menjadi persesuaian antara pengetahuan dan objek bisa juga diartikan suatu pendapat atau perbuatan seseorang yang sesuai dengan (atau tidak ditolak oleh) orang lain dan tidak merugikan diri sendiri. Berikut ini tabel hubungan pengelolaan

\begin{tabular}{|l|l|}
\hline 2. Transparansi & $\begin{array}{l}\text { Ada' } \\
\text { Tongeng }\end{array}$ \\
\hline Penatausahaan ADD : & Sipakatau \\
1. Akuntabilitas & Lempu' \\
2. Transparansi & $\begin{array}{l}\text { Ada' } \\
\text { Tongeng }\end{array}$ \\
\hline Pelaporan ADD : & Lempu' \\
1. Akuntabilitas & Ada' \\
2. Transparansi & Tongeng \\
\hline Pertanggungjawaban & Lempu' \\
ADD : & Ada' \\
1. Akuntabilitas & Tongeng \\
\hline
\end{tabular}

Terkait pernyataan tersebut mengingatkan pada lima masalah pokok kehidupan manusia dalam setiap kebudayaan yang dapat berimplikasi terhadap proses pengawasan anggaran Alokasi Dana Desa, di mana hal ini sangat mempengaruhi sikap dan wawasan pemerintah daerah tentang hakikat hidup yang tidak hanya diperuntukkan bekerja untuk kesenangan sendiri dengan mendapatkan kekuasaan, status, jabatan dan kedudukan, tetapi bagaimana bekerja untuk memperlihatkan sebuah prestasi atau karya-karya agung dengan orientasi waktu yang tepat dengan tetap memperhatikan hubungan antar manusia sehingga tercipta sistem tata kelola pemerinta yang baik yang tidak hanya 
dinilai sebagai pertanggungjawaban namun juga sebagai apresiasi atas tindakan yang sejalan dengan keinginan prinsipal. Seperti pada masyarakat Makassar maupun Gowa yang memiliki budaya, yaitu budaya siri' na pacce yang dapat dijadikan sebagai pedoman dalam kehidupan.

\section{PENUTUP}

\subsection{Simpulan}

Dari hasil penelitian dan pembahasan yang telah dikemukakan pada bab sebelumnya, peneliti mengambil kesimpulan bahwa :

1. Pengelolaan ADD di Desa Paccellekang terbilang sudah bagus, sesuai dengan prinsip good governance. Pengelolaan pada tahap perencanaan telah menerapkan prinsip partisipasi. Hal ini dibuktikan dengan kehadiran masyarakat dalam forum Musrenbangdes. Selain itu dalam proses musyawarah, pemerintah desa terbuka untuk menerima usulan masyarakat untuk pembangunan di desa dan juga terlibat langsungnya masyarakat dalam pelaksanaan pembangunan desa. Selain itu, dalam tahap perencanaan, secara prosedur sudah sesuai dengan peraturan, namun secara target waktu tidak sesuai dengan peraturan. Pada tahap pelaksanaan yaitu adanya pertanggungjawaban secara fisik dan proses administrasi yang sudah sesuai dengan prinsip good governance meskipun masih ada sedikit kekurangan. Dalam tahap penatausahaan dapat dikatakan sudah sesuai aturan. Tahap pelaporan dapat dikatakan sudah tepat waktu dan sesuai dengan peraturan. Dan pada tahap pertanggungjawaban yaitu adanya pertanggungjawaban langsung kepada pihak-pihak yang berkepentinga dan adanya pelaporan dalam bentuk papan informasi realisasi APBDes.

2. Nilai budaya siri' na pacce dapat meningkatkan pengawasan anggaran alokasi dana desa (ADD) karena sebagaimana pengelolaan ADD berkaitan dengan kejujuran dan tanggungjawab nilai budaya juga memiliki nilai lempu' (kejujuran) dan ada' tongeng (berkata benar) dalam mempertanggungjawabkan suatu perbuatan. Siri' na pacce memiliki pengaruh yang sangat besar dalam menjalankan suatu amanah. Lempu' dalam dimensi akuntabilitas kejujuran yaitu kejujuran dan kebijaksanaan yang menjadi kunci dalam memimpin. Nilai lempu' menjadi penguat dalam pelaksanaan pengelolaan alokasi dana desa yang memiliki makna begitu dalam mengenai kejujuran. Akuntabilitas lempu' pada Desa Paccellekang dapat dilihat dari apa yang terjadi di masyarakat dan dari kualitas pekerjaan yang telah dilakukanoleh pemerintah. Ada' Tongeng adalah sebuah nilai yang berfungsi untuk menjaga kebenaran, kevalidan dan kendala dalam melaksanakan sesuatu. Dengan nilai ada' tongeng (kebenaran) dalam pengawasan anggaran pengelolaan ADD pemerintah sesuai dengan niat, perkataan dan perbuatan sehingga tidak ada pihak yang dirugikan.

\subsection{Saran}

Hal yang diajukan peneliti adalah berupa saran-saran dan keterbatasan yang ada demi untuk perbaikan di masa yang akan datang. Penelitian ini adalah penelitian kualitatif dengan menggunakan pendekatan etnografi kritis, maka terdapat beberapa 
keterbatasan di dalamnya. Pertama hasil penelitian ini hanya berfokus pada satu desa dan waktu penelitiannya yang terbatas. Kedua, walaupun penelitian ini menggunakan triangulasi dalam pengumpulan dan analisis data, akan tetapi tidak menutup kemungkinan terjadinya bias karena sifat subjektivisme peneliti dan kurangnya data yang diperoleh. Hasil dari wawancara, gambar dan data dapat salah ditafsirkan. Meskipun demikian, hal tersebut seharusnya bukan menjadi suatu masalah karena pendekatan apapun yang digunakan peneliti tidak ada yang bebas dari bias subjektivisme.

Oleh karena itu, berdasarkan keterbatasan-keterbatasan di atas maka peneliti yang akan datang diharapkan dapat melibatkan lebih banyak objek. Untuk Desa Paccellekang sendiri diharapkan dapat lebih meningkatkan partisipasi masyarakat dalam meningkatkan pembangunan desa. Menjaga kearifan nilai budaya siri' na pacce dalam setiap aktivitas baik dalam akuntabilitas pengelolaan alokasi dana desa (ADD) ataupun dalam kehidupan sehari-hari.

\section{DAFTAR PUSTAKA}

Adiwirya, Muhammad Firdiansyah. Putu Sudana. 2015. Akuntabilitas, transparansi, dan anggaran berbasis kinerja pada satuan kerja perangkat daerah kota Denpasar. $E$ Jurnal Akuntansi 11.2 (2015): 611628.

Alvianty., Elfreda A Lau, dan Imam Nazarudddin Latif. 2013. Akuntabilitas Pertanggungjawaban Alokasi Dana Desa Tahun Anggaran 2013 di Desa Badak Baru. Akuntansi, Fakultas Ekonomi, Universitas 17 Agustus 1945 Samarinda: 1-7.
Andoh., Quaye, dan Akomae. 2018. Impact of fraud on ghanaian smes and coping mechanisms. jurnal university of new england uploaded by emeraldinsight 08 March 2018.

Astuty, E. dan E. H. Fanida. 2011. Akuntabilitas Pemerintah Desa Dalam Pengelolaan Anggaran Pendapatan Dan Belanja Desa (Apbdes) (Studi Pada Alokasi Dana Desa Tahun Anggaran 2011 Di Desa Sareng Kecamatan Geger Kabupaten Madiun). Accountability, Governance Village, Apbdes: 1-19.

Duadji, noverman. 2012. Good Governance dalam Pemerintah Daerah. MIMBAR, Vol. 28, No. 2 (Desember, 2012): 201-209.

Fatnuriawan, A. 2014. Kinerja Aparatur Pemerintah Desa Dalam Upaya Meningkatkan Mutu Pelayanan Publik Di Desa Puhjarak Kecamatan Plemahan Kabupaten Kediri Tahun 2014. Artikel:1-15.

Fitriyani. 2012. Penerapan AHP Sebagai Model Sistem Pendukung Keputusan. Jurnal Kebangsaan. 5(2).12-45.

Hamzah. 2015. Pengaruh partisipasi penyusunan anggaran terhadap kinerja manajerial dengan motivasi sebagai variabel moderating (Studi Kasus Perguruan Tinggi Swasta di Kota Semarang). Media ekonomi dan manajemen Vol. 30 No. 2 : 190-201.

Hayat, Mar'atul Makhmudah. 2016. Pencegahan terhadap tindak pidana korupsi pemerintahan desa: Kajian politik kebijakan dan hukum pengelolaan sumber daya Alam desa.

Hofstede, G. (1999). Cultures and Organization. McGraw-Hill International (UK) Limited.

Isti'anah. 2010. Penerapan dan implementasi anggaran berbasis kinerja. Jurnal informasi perpajakan 
akuntansi dan keuangan pablik.Vol. 5, No. 1, : 73-84.

Junaidi. 2015. Perlakuan Akuntansi Sektor Publik Desa Di Indonesia.Akuntansi, Anggaran, Dana, Desa. Jurnal Neo-Bis. 9(1) Juni: 39-59.

Kartika, Ray Septianis. 2012. Partisipassi Masyarakat dalam Mengelola Alokasi Dana Desa (ADD) di Desa Tegeswetan dan Desa Jangkrikan Kecamatan Kepil Kabupaten Wonosobo. Badan Penelitian dan Pengembangan Kementerian dalam Negeri. Disetujui 10 Agustus 2012.

Latif. 2013. Analisis Laporan Keuangan Pemerintah Daerah. Panduan Untuk Eksekutif, DPRD dan Masyarakat dalam Pengambilan Keputusan Ekonomi, Sosial dan Politik.

Mahfudz. 2009. Analisis Dampak Alokasi Dana Desa (ADD) Terhadap Pemberdayaan Masyarakat dan Kelembagaan Desa. Jurnal Organisasi dan Manajemen. 5(1): 10-22.

Mahmud. 1996. Pappasang To Riolo. Ujung Pandang: Balai Penelitian Bahasa

Mashal, Ahmad M. 2011. Corruption and resource allocation distortion for "escwa" countries. Internationaljournalof economic and managemen sciences vol. 1 , No. 4.

Mashudi. 2014. Pendidikan Keberagaman Sebagai Basis Kearifan Lokal (Gagasan Kerukunan Umat Beragama). Jurnal Tarbawi Volume 11. No. 1. Januari-Juni 2014.

Neta, Yulia. 2012. Model Tata Kelola Administrasi Pemerintahan Yang Baik di Daerah Otonom Baru. Fiat Justitia Jurnal Ilmu Hukum Volume 6 No. 2 Mei-Agustus 2012.: 1-15.

Randa, Fransiskus \& Fransiskus E. Daremos. 2014. Transformasi Nilai
Budaya Lokal dalam Membangun Akuntabilitas Organisasi Sektor Publik. Jurnal Akuntansi Multiparadigma. 5(3): 345-510.

Rozaki, Eka, Manzur khan, Zuaib. 2005. Akuntabilitas Pengelolaan Alokasi Dana Desa (Studi Kasus Pengelolaan Alokasi Dana Desa di Desa-Desa dalam Wilayah Kecamatan Tlogomulyo Kabupaten Temanggung Tahun 2008). Tesis. Program Studi Magister Sains Akuntansi Program Pasca Sarjana Universitas Diponegoro Semarang.

Sardjito, B. dan Muthaher, Osmed. 2007. Pengaruh Partisipasi Penyusunan Anggaran terhadap Kinerja Aparat Pemerintah Daerah: Budaya Organisasi dan Komitmen Organisasi Sebagai Variabel Moderating.Proseding Simposium Nasional Akuntansi X.Makassar.

Simon,yulius. Masdarmasud. Mahfud nurnajamuddin.dan Muhammad su'un. 2016. The role of apparatus competence, internal control system on good governance and the quality of financial statement information.International Refereed Research Journal Vol.- VII.

Sopanah, Ana.2014. Kearifan Lokal dalam Pusaran Modernitas.Pidato Ilmiah. Malang:1-20.

Sujarweni.2015. Pengaruh Partisipasi Penganggaran Dan Komitmen Organisasi Pada Kinerja Manajerial Dengan Kepuasan Kerja Sebagai Variabel Intervening. Jurnal Akuntansi. 10(1).261-278.

Suwardjono. 2014. Teori Akuntansi Perekayasaan Pelaporan Keuangan, edisi ketiga cetakan kedelapan.Yogyakarta: BPFE Yogyakarta.

Syilvia. 2014. Akuntansi Dalam Persfektif Budaya Jawa: Sebuah Study Etnografi Pada Pedagang Keliling Di Kota Semarang. Jurnal Ilmu 
Manajemen dan Akuntansi Terapan (JIMAT).

Thomas. 2013. Pengelolaan Alokasi Dana Desa dalam Upaya Meningkatkan Pembangunan di Desa Sebawang Kecamatan Sesayab Kabupaten tana Tidung. eJournal Pemerintahan Integratif. 1(1): 51-64.

Verasvera, FebrinaAstria. 2016. Pengaruh anggaran berbasis kinerja Terhadap kinerja aparatur pemerintah daerah (studikasus pada dinas social provinsi jawa barat). Jurnal Manajemen, Vol.15, No.2 : 137-162.

Wolcott, H.F. (1977), Teacher vs Teknocrats : An educational Innovation in an Anthropological Perspectiive. Eugene, Oregon: Center for Educational and Manajement, University.

Wungubelen, R. L. 2014. Pengaruh Kepemimpinan Dan Disiplin Terhadap Kinerja Pegawai Pada Inspektorat Kabupaten Flores Timur. Jurnal Administrasi Publik dan Birokrasi.1(10): 1-10.

Yarnidan. 2016. Penguatan tata kelola pemerintahan yang baik dalam pembentukan peraturan perundang-undangan sebagai pilar penegakan hak asasi manusia di Indonesia. : 120-138. 